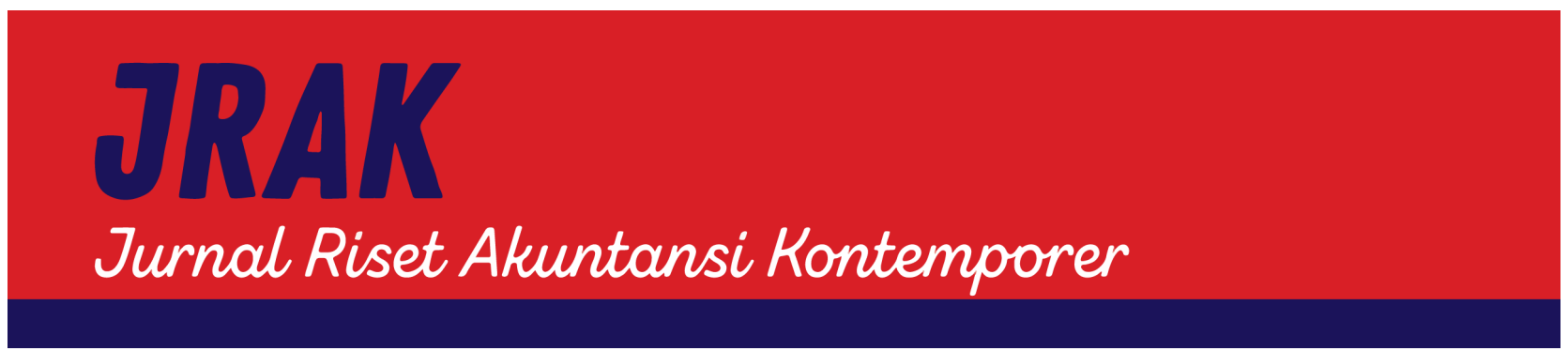

\title{
CONTINUANCE USE OF MANAGEMENT INFORMATION SYSTEMS FOR CIVIL REGISTRATION SERVICES
}

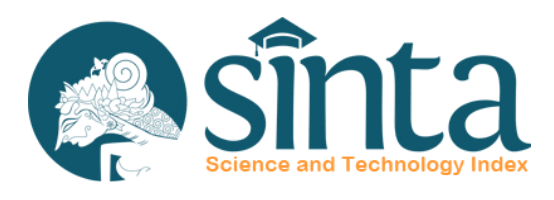

https://journal.unpas.ac.id/index.php/jrak/index

\author{
Ghina Fitri Ariesta Susilon $₫$, Panji Afandi ${ }^{2}$ \\ 1,2Universitas Tidar \\ $\triangle$ ghinafitri.ariesta@untidar.ac.id
}

J1. Kapten Suparman No.39, Tuguran Kec. Magelang Utara, Kota Magelang

\section{Article Info}

History of Article

Received: 19/6/2020

Revised: 5/3/2021

Published: $25 / 4 / 2021$

Jurnal Riset Akuntansi Kontemporer

Volume 13, No. 1, April 2021, Page 37-41

ISSN 2088-5091 (Print)

ISSN 2597-6826 (Online)

Keywords: continuance use; technology; management information system; department of population and civil registration; Magelang City

\begin{abstract}
Department of Population and Civil Registration of Magelang City is a local government agency that run public services effectively and efficiently. It is because the service is oriented to the societies. This study aims to analyze supporting technology as performance support of the Department of Population and Civil Registration of Magelang City namely the Management Information System for Admissions Management of Population Administration Applications (SIMP3AK). This study belongs to the category of qualitative research. This study used interview as its method. The results show that the continuance usage of SIMP3AK is determined by the existence of three indicators, namely, trust, efficiency and effectiveness, and satisfaction.
\end{abstract}

\section{INTRODUCTION}

The use of technology in this era has been applied to fulfill various human needs both individually and in organizational groups. Technology is used to support human activities and has been proven to increase productivity (Susilo \& Rani, 2020). This means that today's human activities cannot be separated from the support of technology.

Technology also serves to form a system that integrates the activities of the users. Technology capabilities are able to form a system that can convey information quickly. The existence of an information system can change various aspects, starting from the way organizations act, interact, communicate, collaborate, to be able to support business activities (Limaj, et al., 2016).

The revolution in information and communication technology has also changed the way governments provide their services to the public ( $\mathrm{Li}$, et al., 2018). The government is trying to improve their services with the support of technology. This is part of the process of modernizing public administration within the scope of government (Veeramootoo, et al., 2018).

The Department of Population and Civil Registration of the City of Magelang is an agency related to the management of population administration in the City of Magelang. This agency has a crucial role in completing public services. This is in line with the stipulation of the Ministry of Utilization of State Apparatus and Bureaucratic Reform of the Republic of Indonesia No. 63/Kep/M.PAN/7/2003 that people have the right to get quality public services and are supported by clear policies. 
As an effort to promote a better public, information technology has been adapted as the main support in the Department of Population and Civil Registration of Magelang City (Afandi \& Susilo, 2021). This technology is implemented in the form of a system called SIMP3AK which has been implemented since early March 2018 in accordance with the direction of the central government which aims to establish better governance (Chrismonita, et al., 2020).

This study aims to analyze the sustainability of the efficiency and effectiveness of the SIMP3AK system in the Department of Population and Civil Registration of Magelang City. Entering the third year of implementing this system, indicators of sustainable use of this technology can begin to be identified. Technology support is very important to facilitate activities when human space and time are limited (Song \& Zhou, 2020). Therefore, SIMP3AK is expected to be one of the supporting factors for the sustainability of efficient and effective public services, especially in the field of population administration in the Department of Population and Civil Registration of Magelang City.

\section{METHOD}

This research was conducted qualitatively. Data was collected through interviews with party respondents who were directly involved in SIMP3AK at the Department of Population and Civil Registration of Magelang City. Previously, a literature study was conducted to obtain references to research questions. The question instrument was modified from several studies (Gao, et al., 2015; Rahi \& Abd. Ghani, 2019; Hsu \& Lin, 2020) which examined the sustainability of technology use and then adjusted it to research SIMP3AK in the Department of Population and Civil Registration of Magelang City. Table 1 shows the lists of our research respondents.

Table 1. The Lists of Respondents

\begin{tabular}{cl}
\hline Informant Code & \multicolumn{1}{c}{ Position } \\
\hline Informant 1 & Head of PIAK Division and Data Utilization \\
Informant 2 & Section Head of Partnership Field and Service Innovation \\
Informant 3 & Operator SIMP3AK in The Department of Population and Civil Registration of the City of Magelang \\
\hline
\end{tabular}

Those respondents were chosen because they have a strategic position in the institution that is the object of the research. Apart from that, they are also involved in the formulation of existing policies related to the management of SIMP3AK. The three respondents were then interviewed directly. The question items used are described in Table 2 below.

Table 2. The Lists of Questionnaires

\begin{tabular}{|c|c|c|}
\hline No & Questions & Reference \\
\hline 1. & Is SIMP3AK easy to use and supports agency performance? & Gao et al., (2015) \\
\hline 2. & Does SIMP3AK provide information that is appropriate and relevant to the needs of agencies? & \\
\hline 3. & Does SIMP3AK get regular renewal and maintenance? & \\
\hline 4. & $\begin{array}{l}\text { How confident is the agency in SIMP3AK regarding the security of agency data that has been entered } \\
\text { into the system? }\end{array}$ & \\
\hline 5. & How has the quality of SIMP3AK been since it was first adapted in this agency? & \\
\hline 6. & $\begin{array}{l}\text { Is SIMP } 3 \text { AK in accordance with the expectations expected by the Department of Population and Civil } \\
\text { Registration of Magelang City? }\end{array}$ & $\begin{array}{l}\text { Rahi \& Abd. } \\
\text { Ghani, (2019) }\end{array}$ \\
\hline 7. & Have the department got benefit from SIMP3AK since the system was adapted in March $2018 ?$ & \\
\hline 8. & How is the level of satisfaction felt by SIMP3AK users from year to year? & \\
\hline 9. & Is there a special internal control system related to the use of SIMP3AK? & \\
\hline 10. & How can the efficiency and effectiveness of the agency's performance be increased after SIMP3AK is used? & \\
\hline 11. & $\begin{array}{l}\text { To what extent does SIMP } 3 \text { AK have a functional value that captures utility based on perceived quality } \\
\text { and performance expectations of agencies? }\end{array}$ & Hsu \& Lin, (2020) \\
\hline 12. & To what extent does SIMP3AK provide pleasure for its users in this institution? & \\
\hline 13. & $\begin{array}{l}\text { What is the positive impact resulting from the performance evaluation between the period before SIMP } 3 \text { AK } \\
\text { was adapted to the period after SIMP } 3 \text { AK was introduced? }\end{array}$ & \\
\hline 14. & Are the costs and time spent on SIMP3AK comparable and in line with the perceived benefits? & \\
\hline 15. & To what extent does this agency intend to continue using SIMP3AK? & \\
\hline
\end{tabular}




\section{RESULT}

The interview process was carried out within one day after coordinating with the three interview respondents. The compiled question items were then submitted to the three respondents to obtain information. Table 3 are describing the answers of interviews from research respondents.

Table 3. The Results of Interviews

\begin{tabular}{|c|c|}
\hline No. & Answers \\
\hline 1. & $\begin{array}{l}\text { "In my opinion, the implementation of SIMP } 3 \mathrm{AK} \text { is good enough. There are already various facilities and infrastructure that } \\
\text { support the performance of Department of Population and Civil Registration of Magelang City" (Informant 1). }\end{array}$ \\
\hline 2. & $\begin{array}{l}\text { "Yes, of course. The establishment of this system aims to facilitate the work assigned to our agency, so that the system is made } \\
\text { according to the needs of the agency" (Informant 1). }\end{array}$ \\
\hline 3. & $\begin{array}{l}\text { "Yes, the SIMP3AK system here gets periodic renewal and maintenance every } 6 \text { months or according to the needs of the } \\
\text { agency. This is so that the system continues to function optimally" (Informant } 3 \text { ). }\end{array}$ \\
\hline 4. & $\begin{array}{l}\text { "Our agency believes that SIMP } 3 \text { AK has good security because this system is made according to the needs of the agency and } \\
\text { can only be accessed by internal operators that we have trained. In addition, the existence of adequate computers and networks } \\
\text { also supports the security of this system" (Informant 2). }\end{array}$ \\
\hline 5. & $\begin{array}{l}\text { "When it was first formed, there was no service approach (printing of KTP or KK) which caused SIMP3AK to have weaknesses } \\
\text { in distribution because the printing of these forms was at the service. However, this problem can be resolved with a service } \\
\text { approach. Another problem also arose, namely the delay in issuing KTP by entry officers. The solution is that we provide } \\
\text { training for the entry officers to operate the system effectively" (Informant 1). }\end{array}$ \\
\hline 6. & $\begin{array}{l}\text { "Until now, SIMP3AK has always been updated, especially during this pandemic we all face limited mobility, so the existence } \\
\text { of a support system is urgently needed. In our opinion, this system is sufficient to meet expectations" (Informant 2). }\end{array}$ \\
\hline 7. & $\begin{array}{l}\text { se, it really helps our work so it can be completed quickly. In addition, people's trust in us has grown again because } \\
\text { ty of our services has improved after this system was implemented" (Informant 1). }\end{array}$ \\
\hline 8. & $\begin{array}{l}\text { "We always read suggestions and criticisms from the public for the services we provide. We make this an evaluation material every } \\
\text { year to be even better. Fortunately, the negative response has decreased because we have improved the quality" (Informant 2). }\end{array}$ \\
\hline 9. & $\begin{array}{l}\text { "Yes, here. For the sake of the smooth running of the SIMP } 3 \text { AK program, as much as possible we can implement it in accordance with } \\
\text { the existing regulations, my boss advised me. I was in the team, the operator with colleagues who are highly skilled" (Informant } 3 \text { ). } \\
\text { "It is true, all SIMP } 3 \text { AK operators can have qualified competencies, especially the ability to implement this system. This is } \\
\text { one of our achievements in fulfilling the internal control aspect" (Informant 2). }\end{array}$ \\
\hline 10. & $\begin{array}{l}\text { "The existence of SIMP } 3 \text { AK is very helpful, although sometimes we still encounter problems with delays in issuing KTPs. } \\
\text { However, in general the implementation of this system has been running quite effectively and efficiently compared to the } \\
\text { conditions before the existence of this system" (Informant 1). }\end{array}$ \\
\hline 11. & $\begin{array}{l}\text { "SIMP } 3 \text { AK was formed by adjusting the need for administrative services which are increasingly being demanded by the } \\
\text { community so that the process runs fast and easy. Therefore, to create good things in carrying out the population administration } \\
\text { process systematically, we always try to establish communication with the community so that this system continues to function } \\
\text { according to function and can meet expectations. agencies" (Informant 1). }\end{array}$ \\
\hline 12. & $\begin{array}{l}\text { "In my opinion, as a direct implementer of this system, it has had a very positive impact. My job as an operator is always done on } \\
\text { time so I don't have to do overtime work. This is an indicator of happiness that I feel after the operation of this system" (Informant 3). }\end{array}$ \\
\hline 13. & $\begin{array}{l}\text { "In addition to facilitating work, this system has a positive impact on agencies. Increasing quality of services, increasing public } \\
\text { trust, and maintaining the efficiency and effectiveness of our services" (Informant 1). }\end{array}$ \\
\hline 14. & $\begin{array}{l}\text { "Yes. In our opinion, the allocated costs and time spent on the system are commensurate with the perceived benefits. The benefits } \\
\text { are not only us who feel, the main thing is the community as users of administrative services. This system really streamlines } \\
\text { their time in the management process" (Informant 2). }\end{array}$ \\
\hline 15. & $\begin{array}{l}\text { "With the various benefits we have felt, we are sure that we will continue to need support from this system to achieve efficiency } \\
\text { and effectiveness of public services in our agency" (Informant 1). }\end{array}$ \\
\hline
\end{tabular}

\section{DISCUSSION}

The government is trying to improve the quality and quantity of services by providing a solution in the form of SIMP3AK. SIMP3AK in government agencies has an important role to be able to present quality reports. This system also functions as a programmable utility that plays a role in increasing the effectiveness of the implementation of the population management system and administrative civil records that are oriented towards several principles, namely, efficiency, economical, effective, transparent, accountable and auditable (Afandi \& Susilo, 2021). 
The existence of a system is considered successful if it provides tangible benefits in various activities of human life (Greeven et al., 2017; Gunadi, 2019). After the benefits of the system are felt by the user, a sense of pleasure will be formed and the desire to continue using the system will appear. Continuous intent stems from a repetitive pattern of behavior that results from certain contextual cues and is directly related to the satisfaction or value the user feels after using the system (Jahanmir, et al., 2020; Puthur, et al., 2020).

SIMP3AK is one of the e-government products. E-government is the conceptualization of the use of information technology by the government that supports organizational change to improve its operational processes (Twizeyimana \& Andersson, 2019). Thus, ideally, SIMP3AK must meet these factors to be included in a form of e-government that is capable of being used in a sustainable manner.

Based on the results of interviews conducted with the three respondents, there are three main pieces of information that can be used to analyze the usefulness of SIMP3AK in the Department of Population and Civil Registration of Magelang City. First, the trust of system users has been formed because of the perceived benefits and security offered by the system. Trust is one of the fundamental factors in the acceptance of a system as a technology supporting activity (Shao, et al., 2019).

Secondly, SIMP3AK has been identified to be a factor that can increase the efficiency and effectiveness of agency performance. One of the expectations of information system users is that the quality of their performance can improve with the support of this technology to form better efficiency and effectiveness (Bandiyono \& Indrianto, 2019). Centobelli, et al. (2018) then emphasized that the effective and efficient performance dimensions of the existence of information systems will form a support system for more targeted and sustainable decision making.

Thirdly, the positive impact of the presence of SIMP3AK is the formation of satisfaction from its users, both agencies and the community as recipients of public services. Satisfaction is obtained from the quality that a system provides to its users (Ramkumar, et al., 2019). Satisfaction is also a predictor of user subjectivity assessment whether they will use the system sustainably or not (Li \& Shang, 2020).

\section{CONCLUSIONS}

This study provides a deeper understanding of the factors that affect the sustainability of the use of SIMP3AK in the Department of Population and Civil Registration of Magelang City. There are three essential factors that have a direct impact on the continued use of SIMP3AK, namely: trust, efficiency and effectiveness, and satisfaction. The three indicators are felt by the user after going through some time and each indicator is identified after the user has benefited one by one in sequence. This research is a qualitative research which has a narrow generalization nature, but the results of this study can still provide an overview of the benefits of implementing information systems in government. In addition, the interviews for this study were conducted at one time with all three respondents directly being asked simultaneously, the possibility of opinion intervention could occur, thus affecting the independence of the opinion of each respondent.

\section{REFERENCES}

Afandi, P., \& Susilo, G. F. A. 2021. Analisis Efektivitas Sistem Informasi Manajemen Penerimaan Pengelolaan Permohonan Administrasi Kependudukan (SIMP3AK) pada Dinas Pencatatan Sipil Kota Magelang. KRISNA: Kumpulan Riset Akuntansi, 12(2), 288-296.

Bandiyono, A., \& Indrianto, N. P. P. 2019. E-Rekon LK Application as a Form of Accounting and Information Systems Implementation in Indonesia. International Journal of Innovation, Creativity and Change, 8(3), 23-40.

Centobelli, P., Cerchione, R., \& Esposito, E. 2018. Aligning Enterprise Knowledge and Knowledge Management Systems to Improve Efficiency and Effectiveness Performance: A Three-Dimensional Fuzzy-Based Decision Support System. Expert Systems with Applications, 91, 107-126. https://doi. org/10.1016/j.eswa.2017.08.032

Chrismonita, V. N., Adriantini, D., \& Dewi, S. 2020. Efektivitas Permendagri Nomor 7 Tahun 2019 tentang Pelayanan Administrasi Kependudukan Secara Daring (Studi di Disdukcapil Kota Magelang dalam Rangka Mewujudkan Good Governance), 2(2), 64-89.

Gao, L., Waechter, K. A., \& Bai, X. 2015. Understanding Consumers' Continuance Intention Towards Mobile Purchase: A Theoretical Framework and Empirical Study - A Case of China. Computers in Human Behavior, 53, 249-262. https://doi.org/10.1016/j.chb.2015.07.014

Greeven, C.S. and Williams, S.P., 2017. Enterprise Collaboration Systems: Addressing Adoption Challenges and The Shaping of Sociotechnical Systems. International Journal of Information Systems and Project Management, 5(1), pp.5-23. 
Gunadi, G. 2019. Qualitative System Dynamics Modelling of The Impacts of Maintenance, Effort, Competence and Collaboration on e-Government Website Availability. Electronic Government, 15(2), 189-212. https://doi.org/10.1504/EG.2019.098671

Hsu, C. L., \& Lin, J. C. C. 2020. Understanding Continuance Intention to Use Online to Offline (O2O) Apps. Electronic Markets, 30(4), 883-897. https://doi.org/10.1007/s12525-019-00354-x

Jahanmir, S. F., Silva, G. M., Gomes, P. J., \& Gonçalves, H. M. 2020. Determinants of Users' Continuance Intention Toward Digital Innovations: Are Late Adopters Different? Journal of Business Research, 115(December 2019), 225-233. https://doi.org/10.1016/j.jbusres.2019.11.010

Li, Yan, \& Shang, H. 2020. Service Quality, Perceived Value, and Citizens' Continuous-Use Intention Regarding e-Government: Empirical Evidence from China. Information and Management, 57(3), 103197. https://doi.org/10.1016/j.im.2019.103197

Li, Yixiao, Yang, S., Chen, Y., \& Yao, J. 2018. Effects of Perceived Online-Offline Integration and Internet Censorship on Mobile Government Microblogging Service Continuance: A Gratification Perspective. Government Information Quarterly, 35(4), 588-598. https://doi.org/10.1016/j.giq.2018.07.004

Limaj, E., Bernroider, E. W. N., \& Choudrie, J. 2016. The Impact of Social InformationSystem Governance, Utilization, and Capabilities on Absorptive Capacity and Innovation: A Case of Austrian SMEs. Information and Management, 53(3), 380-397. https://doi.org/10.1016/j.im.2015.12.003

Puthur, J. K., George, A. P., \& Mahadevan, L. 2020. Understanding Citizen's Continuance Intention to Use e-Government Services: The Case of The Indian Railway e-Ticket Booking Site. International Journal of Business Information Systems, 34(2), 183-203. https://doi.org/10.1504/IJBIS.2020.108343

Rahi, S., \& Abd. Ghani, M. 2019. Integration of Expectation Confirmation Theory and Self-Determination Theory in Internet Banking Continuance Intention. Journal of Science and Technology Policy Management, 10(3), 533-550. https://doi.org/10.1108/JSTPM-06-2018-0057

Ramkumar, M., Schoenherr, T., Wagner, S. M., \& Jenamani, M. 2019. Q-TAM: A Quality Technology Acceptance Model for Predicting Organizational Buyers' Continuance Intentions for e-Procurement Services. International Journal of Production Economics, 216(June), 333-348. https://doi.org/10.1016/j. ijpe.2019.06.003

Republik Indonesia. Kementerian Pemanfaatan Aparatur Negara dan Reformasi Birokrasi Republik Indonesia No. 63/Kep/M.PAN/7/2003

Shao, Z., Zhang, L., Li, X., \& Guo, Y. 2019. Antecedents of Trust and Continuance Intention in Mobile Payment Platforms: The Moderating Effect of Gender. Electronic Commerce Research and Applications, 33(August 2018), 100823. https://doi.org/10.1016/j.elerap.2018.100823

Song, L., \& Zhou, Y. 2020. The COVID-19 Pandemic and Its Impact on the Global Economy: What Does It Take to Turn Crisis into Opportunity? China and World Economy, 28(4), 1-25. https://doi.org/10.1111/ cwe. 12349

Susilo, G. F. A., \& Rani, U. 2020. Peran Ekonomi Digital terhadap Hubungan ASEAN-Korea Free Trade Area (AKFTA). Jurnal Ekonomi Modernisasi, 16(2), 66-72. https://doi.org/https://doi.org/10.21067/jem. v16i2.4827

Twizeyimana, J. D., \& Andersson, A. 2019. The Public Value of E-Government - A literature review. Government Information Quarterly, 36(2), 167-178. https://doi.org/10.1016/j.giq.2019.01.001

Veeramootoo, N., Nunkoo, R., \& Dwivedi, Y. K. 2018. What Determines Success of an e-GovernmentService? Validation of an Integrative Model of e-Filling Continuance Usage. Government Information Quarterly, 35(2), 161-174. https://doi.org/10.1016/j.giq.2018.03.004 